\title{
Disabled Women, Care Regimes, and Institutionalised Homophobia: a Case Study From Poland
}

\author{
Agnieszka Wołowicz ${ }^{1}$ (D) Agnieszka Król ${ }^{2}$ (D) . Justyna Struzik ${ }^{3}$ (D)
}

Accepted: 25 April 2021 / Published online: 27 May 2021

(c) The Author(s) 2021

\begin{abstract}
Introduction The intersection of non-heterosexuality, gender and disability became a prolific field of research among both queer, crip and disability studies scholars, though focusing mainly on Western regions. The article discusses how women narrate their everyday intimate and care-related experiences situated in ableist and heteronormative regimes of Central and Eastern Europe (CEE). The aim of this article is to scrutinise the care regimes as experienced, navigated and reported by non-heterosexual women with disabilities in Poland, a country characterized by institutionalisation, lack of individualised disability support, and state homophobia.

Methods The study is based on qualitative methods, namely semi-structured, in-depth interviews. We conducted interviews with 11 non-heterosexual disabled women living in Poland. The sampling was based on three criteria: gender, selfidentification as a disabled person, and experience with being in a same-sex relationship (8 out of 11 participants were in a homosexual relationship during the time of the interview). All eleven participants identified as non-heterosexual women (most as lesbians, one as bisexual and one as pansexual) and had a congenital physical disability (including cerebral palsy, spinal muscular atrophy, muscular dystrophy). None of the interviewees had an intellectual disability.

Results By tackling care regimes, our analysis explores women's experiences in the context of discursive confusions resulting from being at the intersection of often-contradictory local narrations on gender, disability, and sexuality. We identified three intertwined processes to understand and explore how care regimes work in Poland: (1) the separateness between queer and disabled policies and discourses, (2) the co-opting/obscuring of homosexual relations between women by category of care, (3) familiarisation of care and its consequences for non-heterosexuality.

Policy Implication We suggest that social support systems must better address the needs of non-heterosexual women with disabilities which are profoundly impacted by structural, political and cultural constraints and possibilities.
\end{abstract}

Keywords Disability $\cdot$ Care $\cdot$ Gender $\cdot$ Lesbian $\cdot$ Homophobia

Agnieszka Wołowicz

a.wolowicz@uw.edu.pl

Agnieszka Król

a.krol@uj.edu.pl

Justyna Struzik

justyna.struzik@uj.edu.pl

1 Faculty of Education, University of Warsaw, Mokotowska 16/20, 00-561, Warszawa, Poland

2 Faculty of Medicine, Jagiellonian University Medical College, Krakow, Poland

3 Institute of Sociology, Jagiellonian University, Krakow, Poland

\section{Introduction: in the Nexus of Disability and Non-Heterosexuality}

In recent years, political discourse in Poland has made extensive use of homophobic themes. One example of such practises could be the so-called 'LGBT-free zones', established by numerous Polish municipalities as a symbolic defence shield against 'LGBT and gender ideologies' (Korolczuk, 2020). These zones, even if interpreted as a declaration by local authorities against certain ideas and social changes, tend to legitimise explicit articulation of homophobic and transphobic attitudes in the local populace, and reveal beliefs about who may be counted a citizen, thereby influencing the lived realities of LGBT persons residing in those communities. The neoliberal and conservative politics promoting homophobic 
and anti-feminist attitudes have triggered numerous social protests among many professional groups (e.g., teachers, doctors, nurses) and communities experiencing daily discrimination and social exclusion, among them people with disabilities and their caregivers, LGBT people, and women (Kubisa \& Rakowska, 2018; Król \& Pustułka, 2018, Struzik, 2020). At the same time, ongoing discussions about inequalities, imagined futures, and uncertainties about the present have led to intensified nationalist and 'alt-right' legislative projects, demanding the defence of the 'traditional' order, a total abortion ban, protection against 'gender and LGBT ideologies', and the strengthening of the position of a nuclear, heterosexual family as the centre of social life (Korolczuk, 2019). In this context, calls for mutual care and solidarity among the groups at the centre of xenophobic, homophobic, and anti-feminist discourse have become more salient in recent years in Poland.

The events briefly described above demonstrate a greater, recent shift within discursive configurations of sexuality, as well as the rights and autonomy of citizens regarding their sexual lives, bodies, and intimate relationships. Taking these events and processes as a point of departure, the following article will examine care-related experiences found at intersections in the social lives of two minorities: LGBT people and people with disabilities. Through the exploration of experiences of non-heterosexual women with disabilities in the context of a Central and Eastern European (CEE) country, we would like to contribute to existing discussions on universal categories: intersectionality, care, and systemic discrimination of LGBT people with disabilities, in circumstances where the rights of these two groups are often violated. Thus, the aim of this article is to scrutinise the care regimes as experienced, navigated, and reported by non-heterosexual women with disabilities in Poland. We want to contribute firstly to centring the articulated experiences of populations that have been invisibilised and denied a proper space in public discussion, due to ableism, homophobia, and sexism. Secondly, while care is a central category for disability studies, it has not been examined extensively in the context of non-heteronormativity; accordingly, the impact of homophobia on access to care has not been thoroughly examined, either. By bringing together and cross-fertilising areas of study that are rarely examined jointly, we want to highlight the intersectional consequences of institutionalised homophobia which could not otherwise be made explicit. By analysing the case of Poland, we showcase how structural, discursive, and institutional contexts for denying LGBT + recognition and rights can impact the everyday lives of non-heterosexual women with disabilities; furthermore, we may examine what the role of care is, in this realm. While we do focus on a local context, the study may be situated within broader disability and sexuality studies, as well as research on the intersectional impact of anti-gender mobilisation, including the disability community. The polarisation of discourses on LGBT rights, due to anti-gender mobilisation, persists in many Central-Eastern European countries, including Hungary, Georgia, the Ukraine, and Russia, though it may also be seen in Western Europe, the USA, and Latin America.

While LGBT rights have been symbolically associated with liberal and leftist politics throughout the last several decades, the rights of people with disabilities in Poland have often been discussed through a more conservative, charitybased, and traditional lens. This could be related to a more general perception in society-one which is reproduced and strengthened by formal care institutions-that people with disabilities are non-sexual social subjects without agency and sexual desires, a notion which has been translated into the exclusion of this group from discussions on sexual and reproductive rights in Poland (Wołowicz-Ruszkowska 2016, Król, 2018). In contrast to many Western countries, only recently have we observed the mobilisation of people with disabilities who are demanding interdependent living, reproductive, and sexual rights. Others are merging disabilityrelated postulates with progressive agendas, for instance within feminist and LGBT movements (Żeglicka et al., 2019). Given this context, the article presents results from an exploratory, qualitative study conducted among non-heterosexual women with disabilities, which has focused on their experiences through the lens of care regimes in Poland. We define 'care regimes' as the social and political (and moral) economy of care, through which formal and informal institutions shape everyday care and (in)security practices. We narrow down the definition of care regimes to the needs, practices, and experiences of non-heterosexual women with disabilities, though we acknowledge that any care practice is situated and shaped by a multiplicity of factors in the scope of current social policy worlds (cf. Shore \& Wright, 2011). The theoretical background of this study emerges at the intersection of the disability studies, concepts of care, and theories that explore queer liaisons, identities, and practices.

Structurally, this article is divided into several parts. First, we present theoretical frameworks regarding care, care practices, and disability. Secondly, we introduce the localised realms of disabled persons as well as LGBT persons and the challenges they have faced in recent years in Poland, as articulated in the review of social research. We discuss the methods used in the study and introduce the results, which are followed by a discussion.

\section{Caring, Disability, and Intersectionality}

Since the 1980s, researchers have indicated a growing need for applying a gendered lens when exploring experiences of people with disabilities in different areas of life (Thomas, 1999; Traudstadóttir, 2006). Although an increasing number of studies addressing issues of women with disabilities (e.g., through an intersectional perspective) can be observed, there is still a risk that this group may be perceived as homogenous, 
and its internal diversity, produced by such factors as socioeconomic status, type of disability, sexual orientation, gender identity, place of residence, age, etc., may not receive attention. Studies in this field focus on the limited access to the labour market, while sexuality, reproductive decision-making, or engaging in a relationship-especially in non-Western contexts-is still a niche topic. This is certainly the case in the Polish context, in terms of experiences of non-heterosexual women with disabilities. The processes followed by women with disabilities when making decisions about intimate relationships, sexual life, and reproductive choices, despite social, economic, cultural, and physical constraints require further investigation in the realm of non-normative choices, which are easily overlooked by scholars and professionals.

Care has often been equated with reproductive labour, in terms of addressing basic, biological needs as well as with respect to those activities which reproduce and sustain relationships and bonds between people over time (Schwarzenbach, 1996; Engster, 2005; see also caring as a 'labour of love' in Graham, 1983; Hochschild, 1995). From such a perspective, caring is defined as an activity that happens between two people and engages their bodies, emotions, and minds (Hochschild, 1995). But caring has also been described as a burden or a certain obligation for those who provide it, and as a potentially oppressive practice to those who are taken care of (Evans \& Atim, 2011). The gendered aspect of unpaid versus paid care work, delivered by women, is a widely recognised phenomenon in social sciences; however, women with disabilities are more often perceived in the role of those who receive care rather than those who take care of other relatives and dependents. Care involves continuous tensions between vulnerability, agency, and independence (Evans \& Atim, 2011); these notions pertain to both recipients of care and caregivers (Kittay, 1999). Importantly, disability scholars have been struggling with the notion of care, "claiming that the notion carries an understanding of disabled (and older) people as passive and dependent recipients and that this kind of perspective makes it impossible to really comprehend and promote empowerment and an independent life' (Kröger, 2009 , p. 398). The main arguments provided by researchers suggest how care may become entangled with the dependency of those who need support. In many studies, as Kröger shows (2009), the descriptions of care-based relations do not generally go beyond such terms as 'the cared for', 'caretakers,' or 'care receivers', seeming subordinate or dependent. 'Crip' scholars emphasise that the need for care has produced a multiplicity of harmful, unjust, and exploitative practices in various social settings: "claiming to "care for" people with disabilities as a socio-medical category has justified segregated education and living arrangements, institutionalisation, abuse, sterilisation, painful and ineffective treatments, and many other harms to disabled bodies' (Douglas et al., 2017 , p. 3). This is even more evident when applying an intersectional framework to discussions of the complexities of care practices. The intersectional approach remains the key theoretical framework for the analysis conducted, as the theory of intersectionality highlights that overlapping identities are not created on the basis of a simple 'sum' of experiences gained from belonging to different groups, but that they create new and complex qualities/subjectivities (Crenshaw, 2009; Hill Collins \& Bilge, 2016). Parallel to its international impact driven by black feminist scholars, intersectionality has also gained significant recognition in Polish gender studies research, especially in the domains of sexuality, class, and migration status (Struzik, 2015; Hryciuk \& Korolczuk, 2013; Pustułka, 2015). Consideration of the intersections in the field of disability studies is relatively minor, with gender and disability only having been studied in recent years (Ciaputa et al., 2014; Wołowicz-Ruszkowska, 2015).

The notion of care regimes shifts attention from the relations and practices happening between individuals (such as those in need of care and those delivering care) to institutional and formal care, which are often based upon and operating through implicit biases and systemic inequalities. Care institutions may reinforce social perceptions of people with disabilities as non-sexual, or heterosexual by default. One way of overcoming the unequal relationship between a caregiver and a care recipient, often inherent within the notion of 'care' itself, is to show a universal aspect in the rationality of care. Claiming a certain commonality-that everybody is potentially vulnerable and may need support—makes caring an 'all-inclusive' notion and does not assign care practices to particular groups, such as people with disabilities, those experiencing illness, the elderly, and so forth. On the other hand, scholars and activists working in the field of disability (cf. Kittay, 1999, 2011), migration (Tickin, 2011), or trans women of colour in prison (Hwang, 2019), claim that it is necessary to develop further discussion on the notion of care and redefine it by showing its entanglements with existing and unequal relations and orders, paternalist practices, and exploitation of various populations within care activities. Following these analyses, in this article, we contribute to deepening the discussion on the category of care by relating it to the situation of non-heterosexual women with disabilities. We explore how care practices are perceived, experienced, and mediated by non-heterosexual women with disabilities, both in institutionalised and non-institutionalised settings.

\section{Disability and Care Regimes in Poland}

Further analysis requires contextualisation of the care system for people with disabilities, which can be broadly divided into those regulated by the State, and informal practice. Regulated care, which is provided in medical settings, boarding schools, or through caregiving services, is deficient though dominated by large institutions, rather than community 
settings. The informal care (still regulated yet unpaid) is given most often by women, and in-home settings are most common. Given the scarcity of community-based care services, both formal and informal care practices are co-related and shape each other. This process is intermediated by the general care deficit in an ageing society (Kubicki, 2017).

The care model based on the informal sector (with an emphasis on the immediate family) is sustainable and stems from a combination of cultural and institutional conditions in many CEE countries. As mentioned above, most daily care work takes place outside the institutionalised system, in family homes (numerous persons with disabilities live with their families of origin). In Poland, further familialisation of care policies in the post-transformation period, with a rollback on care facilities, may be observed. The explicit familialism paradigm (Szelewa, 2017) entails delegating care to the domain of the family, through the construction of care policies. Care in families is seen predominantly as the role of the mother (Titkow et al., 2004), despite feminists' efforts towards introducing gender equality measures, manifested in recent public negotiations of gender regimes (e.g., the women's strike in 2016; strikes by mother-carers of children with disabilities, 2014, 2017). Their struggles are consistently countered by anti-gender mobilisation (Korolczuk \& Graff, 2018) and the recent deterioration of women's reproductive rights, particularly in the studied country. In recent years, protests by mother-carers, who are the primary caregivers for their children with disabilities, began because they lose the right to work if they receive family disability benefits (Kubicki, 2015). The carers' postulates included implementing respite care-a provision that would ensure professional support for a few hours per month, as in most EU countries, care responsibilities are organised to ensure a balance between family and professional lives (Bakalarczyk, 2015). Given (sometimes total) dependency on support from family members, persons with disabilities may exercise diverse levels of autonomy and independent living, though often they face obstacles when they challenge family expectations, including heteronormativity.

The system of public institutions providing support for people with disabilities is characterised by inefficacy, a paternalistic approach towards patients, low responsiveness, lack of cross-sectoral approaches, and inability to ensure continuity and stability of long-term support throughout one's lifetime (Skrzypek, 2018; Gąciarz, 2014). More comprehensive theorisation at the macrostructural level remains an underexplored area in Poland, especially as the 1989 transformation from socialism to capitalism was only a partially effective, if not ambivalent mechanism for changing disability policies, similarly to other CEE post-socialist states (Mladenov, 2017). Although a discursive change has occurred in academia (in debates over the social model of disability, cf. Gąciarz, 2014), there has been little substantive and multilevel change in disability policies, practices, and attitudes, to date. Since
Poland-like many other post-socialist countries has not gone through an effective process of deinstitutionalisation and individualisation of support-living in an institution remains the only guaranteed form of substantial support, if no family care is available. Despite inclusive education, special schools accommodate around half of disabled pupils. A lack of systemic support in independent adulthood means returning to family homes after graduating or being placed in residential care institutions (also organised by the Catholic church). Independent living in adulthood lacks real structural government backing, and personal assistance has not been fully implemented, though public opinion has drawn attention to the issue for many years. In fact, it is mainly non-governmental organisations which provide user-led services; yet, these are typically regional programs. Moreover, as Kubicki put it in his recent analysis of public disability policies, 'institutional resistivity' is systemic in nature (Kubicki, 2017). As such, there is a lack of response to the intersectional needs of clients, which leads to the fragmentation of disability (a complex, multidimensional phenomenon) within social welfare programs. In addition, such a system reinforces understanding of disability as a 'totalising' feature that dominates other aspects of identity and outweighs other intersecting statuses (e.g., gender, ethnic background, and sexual orientation) (Prilleltensky, 2003).

Both formal and informal care are underpinned by rules on who can access care, why, when, and on what conditions. The implicit assumptions in care practices relate to dominant cultural scripts within the social order. Thus, among others, they tend to rely heavily on heteronormativity and produce experiences that disabled queer persons carefully navigate.

\section{Institutionalised Homophobia and the Experiences of LGBT Persons}

Regarding the situation of non-heterosexual persons after 1989 , a substantial change regarding the visibility of emancipatory claims has been observed, contrary to what has been described above, in disability rights. An unquestionable discursive shift and the proliferation of LGBT activism (including a significant rise in the number of non-governmental organisations and informal initiatives) have not, however, translated into legal protections (Struzik, 2020). Poland remains the largest EU Member State that does not legally recognise same-sex relationships; anti-discriminatory regulations apply only to the labour code, and anti-LGBT hate speech and hate crimes remain widespread but are not punishable, as such (Godzisz \& Viggiani, 2019). LGBT rights organisations and initiatives are not supported institutionally by the State and are subject to attacks. The downplaying and harassment have intensified over the past years, due to fostered political discourse against 'gender ideology', which is widespread in the CEE region and beyond (Korolczuk \& Graff, 2018; Kováts, 2018; Rawłuszko, 2019). Recently, 
more explicit articulation of homophobia by state officials in many countries can be seen, while social attitudes are undergoing intensified polarisation.

Macrolevel hostility translates into individual experiences: according to the regular research by the organisation Campaign against Homophobia, 68.9\% of LGBTA persons have encountered at least one type of violence; $63.72 \%$ have experienced verbal abuse, $33.96 \%$ - threats, $14.11 \%$-sexual violence, and $12.84 \%$ - physical violence. Less than $4 \%$ of LGBTA people who experienced violence motivated by homophobia and/or transphobia reported it to the police. Coming out about one's orientation to the family remains a decision based on strategic choices, for many- $50 \%$ of LGBTA people hide their orientation from neighbours and landlords, $71 \%$ do so at the workplace, and $73.3 \%$ remain hidden at school or university. Only $25 \%$ of mothers and $12 \%$ of fathers fully accept the non-heterosexual orientation of their children (KPH, 2016). Women (mothers or sisters) are more often informed about a same-sex relationship than men (brothers or fathers) (Mizielińka et al., 2014). As the Catholic church remains a crucial player in shaping post-transformation Poland, with regard to both disability and non-heterosexuality (Hall, 2016), it is important to highlight that $43 \%$ of LGBT persons are affiliated with the church, while among their parents this figure reaches over $90 \%$ (Mizielińska et al., 2014).

Due to the intersection of gender and sexual orientation, lesbian and gay experiences differ in other aspects. The experience of non-heterosexual women is marked by invisibility in the public sphere, assumption of its temporality, and non-sexual and friend-like character; lesbians are also exposed to economic difficulties due to discrimination against women in the labour market (Struzik, 2012). Although there is a widespread belief in society that lesbian women's relationships are more widely accepted, a surprisingly inverse association has been proved in research; men's gay relationships were more often accepted by family who knew, which may be explained by stronger expectations of compliance concerning female gender roles (Mizielińska et al., 2014).

Although there is growing empirical research on the social situations of LGBT people, the category of disability is rarely considered (Ferens \& Sikora, 2016). The survey conducted regularly by the Campaign Against Homophobia shows that $3.9 \%$ of respondents have current, official disability certificates (KPH, 2016), a figure that reveals the underrepresentation of disabled persons-estimated to be between 12 and 14\% of the population (GUS, 2016). This might be explained by various hypotheses, including the discursive and policy-level division between disability and the queer communities, which in turn upholds beliefs about the separateness of these groups' experiences. What is evident from the empirical data is that persons living in same-sex relationships face obstacles in contact with healthcare providers, such as the inability to visit a partner after surgery, and restrictions related to insurance, childcare, or inheritance (Mizielińska, Struzik et al., 2017). However, with regard to unequal treatment in health care, it should be emphasised that sexual orientation and gender identity are not generally disclosed in contact with medical professionals (according to $76 \%$ of respondents). Among those who have disclosed this information, $12 \%$ of lesbians and $17 \%$ of bisexual women have encountered unequal treatment (in comparison to $10 \%$ gay men, $12 \%$ bisexual men, and $27 \%$ of transgender persons). Due to minority stress, the LGBT population exhibits more symptoms of poor mental health. For example, symptoms of depression are declared by more than $73 \%$, while according to the EHIS, the rate averages $16 \%$ in the general population (KPH, 2016).

\section{Method}

The study is based on qualitative methods, namely, semistructured, in-depth interviews. Qualitative narrative methods were chosen, as they allow exploration from the emic perspective, for the comprehension of the individual's subjective experiences in relation to the studied phenomenon (Smith-Chandler \& Swart, 2014). The interviewees were prompted with an opening question to describe what it is like to be a non-heteronormative woman with a disability, and the response was then supplemented with follow-up questions. The interviews were the first exploratory phase of the study, conducted in 2017; the research is now being continued as part of the Queer people with disabilities in Poland research project.

Before starting each interview, the interviewer explained the purpose and content of the interview, answered any questions participants had, and obtained written informed consent. Interviewees did not receive remuneration for participating in the research and were informed about this before the interviews. Interviewees were told that they could stop the conversation at any time without giving a reason. There was no external pressure to take part in the study, and nobody reported any distress during or after the interview, regarding the recruitment strategy.

The sampling was based on three criteria: gender, selfidentification as a disabled person, and experience with being in a same-sex relationship ( 8 out of 11 participants were in a homosexual relationship at the time of the interview). All eleven participants identified as non-heterosexual women (most as lesbians, one as bisexual, and one as pansexual) and had a congenital physical disability (including cerebral palsy, spinal muscular atrophy, muscular dystrophy). None of the interviewees had an intellectual disability. The interviewees were 30 to 47 years old, the majority of the interviewees ( 7 of 11) had tertiary education, and only one had not completed secondary schooling. Detailed information about the 
Table 1 Participants' information

\begin{tabular}{|c|c|c|c|c|c|c|}
\hline ID & $\begin{array}{l}\text { Fictictious } \\
\text { name }\end{array}$ & Age & Type of disability & Education & Marital status & $\begin{array}{l}\text { Place of } \\
\text { residence }\end{array}$ \\
\hline 1 & Zofia & 30 & Physical disability: cerebral palsy & Higher education & In a relationship & Urban \\
\hline 2 & Agata & 36 & Physical disability: cleft palate and hypoacusia & Higher education & In a relationship & Urban \\
\hline 3 & Monika & 44 & Physical disability: cerebral palsy & Secondary education & In a relationship & Smaller city \\
\hline 4 & Magda & 46 & Physical disability: cerebral palsy & Higher education & In a relationship & Smaller city \\
\hline 5 & Olga & 40 & $\begin{array}{l}\text { Sensory disability: sightless } \\
\text { woman }\end{array}$ & Secondary education & Single & Rural setting \\
\hline 6 & Agnieszka & 47 & Physical disability: spinal muscular atrophy & Primary education & Single & Rural setting \\
\hline 7 & Iwona & 40 & $\begin{array}{l}\text { Sensory disability: sight } \\
\text { damage; physical disability }\end{array}$ & Higher education & In a relationship & Urban \\
\hline 8 & Ada & 32 & Physical disability: Muscular dystrophy & Secondary education & Single & Smaller city \\
\hline 9 & Sylwia & 37 & Physical disability: Heart disease & Higher education & In a relationship & Rural setting \\
\hline 10 & Beata & 36 & Physical disability: muscular dystrophy & Higher education & In a relationship & Urban \\
\hline 11 & Justyna & 39 & Physical disability: spinal muscular atrophy & Higher education & In a relationship & Rural setting \\
\hline
\end{tabular}

interviewees is presented in Table 1. The interviewees were identified using snowball sampling and criterion methods (Rubin \& Babbie, 2010). Participants were recruited with the support of disability or LGBT non-governmental organisations, and online (through blog websites)

The interviews took place at the locations suggested by the interviewees, mostly at homes and in public spaces. For the stories to be expressed freely, we ensured that the places were safe and accessible to participants (including accessible transport). The sample does not include women living in institutions; yet, two of the participants had experience with living in educational institutions while separated from their families, in childhood. The absence of this group is due to the complex nature of recruitment, the need to negotiate access to participants with gatekeepers (e.g., managers and carers). As one of the sampling criteria was connected to sexual orientation, we could not assume that it would be known to the institution staff, nor we did want to harm participants by exposing them to the potentiality of experiencing homophobia.

During the research, we encountered attempts to control access to information by family members or partners, who interrupted the interviews, even when privacy had been requested. As we aimed at limiting third-party influence, we insisted on conducting individual interviews; yet, in two cases, it was impossible (the mother or the partner of an interviewee continued to be present, supplement the narration, or depreciate the statements). Although unexpected, we perceived these challenges as important dimensions of the fieldwork. These interventions suggested that some of participants negotiate family relations where autonomy is limited, which is consistent with other, more explicitly communicated research findings.

The interviews were recorded, transcribed, and analysed in Polish. The information obtained from the interviews was analysed using narrative analysis. To ensure anonymity, fictitious names have been assigned to all interviewees. The data from the interviews were coded using NVivo. The authors summarised the themes central to each interview. Interview summaries were integrated to develop a code list or a systematic listing of concepts. Using the code list, the transcript of each interview was coded on a lineby-line basis. During the coding process, the code list was refined and expanded to accommodate all the concepts and ideas included in the interviews. Finally, coded text segments relating to each of the interviews were read in turn for themes and patterns.

\section{Results: Mediating the Experience of Homosexuality by the Category of Care}

One of the issues broadly discussed during the interviews concerns various strategies and tactics employed by women with disabilities to overcome the non-sexuality assigned to them, as well as the primacy of care over other forms of relations. The research participants mentioned that they are rarely seen as non-heteronormative women; disability is often seen as a totalising category that overshadows other identities and experiences. As one study participant described it:

'A person like me has to overcome several difficulties. First, those around have to notice that a person in a wheelchair is a person, then an adult, and then that the person is a woman, and then, that the person is non-heteronormative.' (Justyna, physical disability, rural setting).

A one-dimensional, disability-centred perception of the living experiences of disabled women makes it difficult for them to articulate their individual sexual and intimate needs, and desires, even to close family members and friends. 
Families often do not recognise the sexual, intimate, and relationship needs of people with disabilities, even if they are heteronormative, because of processes of infantilisation, over-protectiveness, and the unspoken assumption of non-sexuality.

'When I started using a wheelchair, everyone already thought that I would definitely never have any erotic life - that I sit at home and read books and am cut off from everything, to the point where if someone hears that I' $m$ going on a date, there is this total shock and disbelief. And in the end, because I don't go out much, I haven't encountered many of those cases, though among my own family and friends, it's as if...like as if the moment I sat down in this chair...in spite of the fact they'd known me walking before, to them it's like any sexuality of mine just evaporated, and doesn't exist.' (Agnieszka, physical disability, rural setting).

However, interviewees often claim that, in heteronormative and ableist social orders, they live in not only picture them as non-sexual but also frame any relationship (including heterosexual) that they may potentially form as being based on care. When women with disabilities decide to voice the need to be in a relationship, their families of origin and friends assume that it is only about ensuring themselves care provision. That silences their sexual and emotional needs. One of the interviewees explained:

'I sometimes hear: "You are probably afraid of guys because you are disabled, because you're afraid the guy is strong - and you probably want a caregiver". People see it... even in all these regulations: a person who is with me and has an ID or is 18 years old, is my legal guardian. We are on the bus and s/he is my guardian. And with such nomenclature. [People say that] I'm looking for. I'm not looking for a partner, I'm not looking for a romantic relationship, or a platonic one, I want a caregiver. Someone to support me, someone to carry me, someone to (pardon me) wipe my ass. In general, I have an impression that a person with disabilities looking for a partner is quite often perceived as looking for someone who will take care of this person.' (Iwona, sensory disability, urban).

The primacy of care when thinking about disability also introduces a degree of confusion into the very definition of an intimate relationship, because care-as an activity that enters the intimate register of daily being in the worldinvolves subtle negotiations of gestures of intimacy to be either caring or loving. The respondents have often pointed to the ambiguity, and difficulty, associated with non-formalised care giving meaning to relationships between women. Recognising a difference between 'pure friendship' and being 'in love' is thus hampered by care practices, often provided to women with disabilities by other women.

'Well, we met for the first time at the airport. And. well, it was really nice because she... I was in shock because she gave me a gift. It is strange to me that when I meet somebody for the first time... and she gives me a gift and it was all very nice to talk with her and...for example...then on the plane, as we were flying to Italy, she was holding my hand all the way. It was also very strange to me, because. because it's strange that when I don't know a person. And then it turned out that unfortunately. That is unfortunately for me, because I had already got into it, do you know what I mean? And I felt it then that it was something. And then it turned out that she was actually doing it all out of pure friendship. She was my assistant, the leader of the group. We talked a lot. And she was so terribly open, and yes, after a week, I already knew what it was all about, and that I had fallen head over heels in love.' (Olga, sensory disability, rural).

Another dimension of mediating the experience of homosexuality by the category of care involves coming out, itself. In an often-hostile, heteronormative reality, the disclosure of homosexual or bisexual identity may be linked with fear of the family's reaction. Notably, the need for care or supportand one's dependence on the family - can further complicate the process of coming out, as rejection may mean the loss of the support necessary in daily life. This problem is frequently mentioned in the context of counteracting violence against people with disabilities, as one of the main reasons for staying in an abusive relationship is defined to be nondisclosing due to fear of lack of future support (Saxton et al., 2001). In addition, questioning heteronormativity exposes people to homophobia. This may translate into control of the sexuality of women with disabilities by their families of origin. The possibility of creating intimate relationships is conditioned by the acceptance of non-heteronormativity, or its lack, in the family. What it boils down to is a practical question, such as, "will my Mum drive me to a lesbian date?'.

'It was more or less when I got involved with a girl I was friends with, and I wanted to tell my Mum. I had been talking to my girlfriend and friends about how to do it. And I had a nervous breakdown, which happened to me very often because it was high school. I was 16, and I sat and cried, and my Mum came to me and asked why I was crying, and I told her that she needed to know that I was a lesbian and I couldn't keep it from her any more. And I was prepared that it'd be terrible, but my Mum hugged me and told me that she was glad that I had fallen in love with someone and that it was okay and that she always supported me in that relationship, and also when I finished it, then in some other matters, including how to organise the transport for my dates.' (Zofia, physical disability, urban).

It is not surprising that, due to common homophobic attitudes in Poland, some of our respondents find this situation of invisibility ambivalent, yet quite comforting, and use it as a strategy to navigate through hostile environments. Care and its social perception become a 'protective shield' against homophobic attitudes and acts. 
'Some people indeed see us as two friends - one is in a wheelchair, so the other one is helping her. It simplifies things a lot. For a very long time, everyone thought that she is my assistant. She came to me every day. We did everything together. We didn't correct anyone's mistakes. And that was the safe way, when you live in a small town.' (Monika, physical disability, small city).

Participants of the study highlighted the complex navigation they undertake when coming out, considering not only personal safety but also the provision of necessary, everyday support. They point out the lack of spaces where their identity can be fully embraced, and the separateness between LGBT and disability rights discourses and activism.

'I live in a country where homophobia is increasingly replacing respect for diversity. I therefore fear for my safety and that of my loved ones. In my opinion, in most cases, nonheteronormative women with intellectual, motor, or visual disabilities, who require support in everyday activities, do not decide to come out to their relatives, because the consequences could grossly threaten their quality of life. They risk lack of acceptance, loss of support in daily activities, exclusion from their community, not to mention being banned from integrating into the LGBTQ community. [...] Above all, the topic of non-heteronormativity of people with disabilities and their sexuality are taboo topics. On the one hand, organisations supporting people with disabilities sweep the issue under the carpet. On the other hand, LGBTQ organisations rarely offer us support and do not write about us on their portals. And yet here we are.' (Iwona, sensory disability, urban).

\section{Institutions, Care, and Uncertainty}

The experiences of non-heterosexual women with disabilities are also shaped by relations with institutions of broadly understood care (including education or health care). This applies both to institutions which address their activities directly to people with disabilities and those which offer services to the general population. The institutionalisation of disabled persons shows how controlling sexuality (for example, through the implicit, assumed heterosexuality of all clients) is intertwined with care provision. Some of the interviewees attended boarding facilities that were segregated based on both gender and type of disability, and which were historically designed to limit the reproduction of disabled persons; even now, they hardly provide any privacy. The process of segregation, as a structure and a social practice embedded in staff attitudes, is based on heteronormativity and thus assumes that non-heterosexual relationships do not exist, or are not important because they do not lead to reproduction. The state-regulated experience of gender-separated institutionalisation prompted one of the interviewees to question whether her living in a women-only institution had shaped her sexual orientation, to a certain extent.
'It was a Catholic institution and there was quite a strict division of boys and girls. That is, of course, the school was co-educational, but dormitories of residence weren't. And these dormitories were quite far away from each other and I sometimes wonder if it had or could have had any influence...although it is known that...from what I know about sexual preference, it takes shape well before, right.? During the foetal development, doesn't it? But I sometimes wonder if that had any additional influence.' (Olga, sensory disability, rural setting).

In spite of the predominant homophobic discourse in such institutions and organisations, as demonstrated by the study participants, there was a chance to create accepting queer spaces among the residents.

'There was a lot of anxiety, because. there was also something in me when I was still a Catholic, religion stirred in me a terrible fear connected with being beaten in Catholic schools, that our God will punish us, and it was somewhere deeply rooted in me, so when I fell in love with my friend it was primarily, "God, I'll go to hell", "God, this is bad, what is happening to me, it is somehow unclean and evil". On the other hand, I was lucky to have been in a boarding school in a room with a girl whose best friend was a lesbian, and she was with us at school, too, and. I did not talk to her a lot, maybe more than twice, but these conversations gave me a lot because she was so free and she felt very good with her orientation.' (Zofia, physical disability, urban).

On the other hand, institutions that address their activities and care practices to the general population often fail to recognise the needs of non-heterosexual women with disabilities and reproduce the heteronormative social order. When an individual decides to come out as a queer person, they may experience direct homophobia, disregard, and unequal treatment. Some of the respondents experienced such behaviours while coming out as lesbians in healthcare facilities.

'When I was in hospital, from the moment I said I was a lesbian, they stopped responding to my requests for pain medicine. They ignored me. Disregarded me. And sometimes reviled me.' (Monika, physical disability, small city).

The predicaments of having an inadequate care system for people with disabilities, dependence on support from the family of origin, and a lack of legal protection for the LGBT community all contribute to the research participants' perceptions of care regimes as hollow and porous. They do not receive adequate support, or have to hide their identity to receive support. The care systems remain unresponsive to the needs of this group.

'As a homosexual person, I encounter refusal of treatment. The physiotherapist from the hospice in I have a birth defect of connective tissue and it's very difficult to find a physiotherapist who wants to work with this disease, and I asked him - he is a volunteer for the foundation -and I asked him if he knew anyone he could put me in touch with. And 
everything would have been fine if he hadn't noticed KPH (Campaign Against Homophobia) on my Facebook profile, as we communicated through Facebook, and he claimed that he was not going to help such people, and that he was not going to treat me, and he was not going to put me in touch with any doctors, as such people should end up in a gas chamber This man works in the hospice.' (Iwona, sensory disability, urban).

Sometimes, public institutions operate through homophobic and prejudice-based norms, while the families of origin become more open and accepting toward non-heteronormative identities. Zofia's case demonstrates how her mother's intervention protected her from a violent, harmful, and discriminatory approach towards homosexuality, reproduced by the school she attended.

'[In a small] Catholic boarding school, they caught me a few times crying, I did not eat, so I was sent to a psychologist, I just told her I had a girlfriend [...]. I was called to the principal's office and they asked me whether I was a lesbian, which I thought was quite shocking at the time. And when I nodded, I had to sign a letter that I would go for treatment $[\ldots]$ - it was something like conversion therapy. I called my Mum and, of course, she did not agree to it and I changed schools. [...] It seems to me that people with disabilities are an easy target when it comes to kinds of persecution...even easier because they cannot always defend themselves. They do not always have someone to stand behind them, they do not always have the strength, because they are also in constant pain, for example like me... and it is very hard without support.' (Zofia, physical disability, urban).

An important issue concerning institutional support is the fact that, in Poland, same-sex partnerships are not recognised by law; thus, non-heterosexual couples cannot benefit from legal protections. This situation creates uncertainty for non-heterosexual people with disabilities, for whom care and safety issues are crucial. To the research participants, the lack of legal recognition of same-sex relationships raises additional concerns about formal difficulties regarding care or financial security through inheritance. This uncertainty was expressed by Monika:

'My partner and I would like to go to the notary and sort out our affairs because we're getting older. She's been watching by my hospital bed many times. We would also like to settle our financial matters. We are very much lacking the possibility of legalising our relationship. Very much!' (Monika, physical disability, small city).

The low level of independent housing, the still-undeveloped movement for independent living services, and the economic dependence on the family hinders the establishment of same-sex relationships. The lack of legal protection, and unfavourable economic and social security arrangements for same-sex coupledom, both add further unpredictability and precarity. The sense of uncertainty is also caused by fear of loss or lack of access to institutionalised support when their families are gone, and same-sex coupledom is not protected.

'I can't deal with the fact that I'm disabled. As I say, when the situation is stable, it's fine, but when it's getting worse, I start to panic because it's also connected with the fact that I don't have a family, and, you know, a girlfriend can sometimes be there and sometimes not. Sometimes it gets to me that I'm weak and that my parents are getting old. My brother has his own family. I panic because I'm on my own and I can't deal with it. Let's just say I'm 38, and what will happen in 10, 20 or 30 years if I'm still alive, right? I won't manage on my own. It's more fear of the future.' (Beata, physical disability, urban).

\section{Discussion and Conclusions}

The notion of care regimes allows us to delineate systemic, social, and individual constraints that shape the individual biographies and experiences of non-heterosexual women with disabilities. It also helps one understand the ways queer disabled women make use of the situations that they are in and how they exercise their agency. It demonstrates the strategies and tactics applied to protect the self from homophobia and prejudices, to manifest individual needs and identities, and claim autonomy. To understand how care regimes work in Poland, we would like to point to three intertwined processes, identified in the analysis of narratives on care and non-heterosexuality by disabled women: (1) the co-opting/ obscuring of homosexual relations between women by category of care, (2) familiarisation of care and its consequences to non-heterosexuality, and (3) institutionalised non-responsiveness to the needs of non-heterosexual persons.

Firstly, queer disabled women's experiences are shaped intersectionally by constructs of gender, disability, and sexuality and are often mediated by systemic sexism, ableism, and heteronormative regimes. In Poland, the subtle interplay between these categories leads to an 'invisibilisation' of queer identities, needs, and desires. In the general separation between queer and disability policies and political discourses, visible in the widespread homophobia in disability support institutions experienced by interviewees, the scarcity of reported spaces where intersectional identities can be embraced-including within LGBT + or disability rights movements, which are nonrecognisant of accessibility needs, disability experiences, or non-heterosexual relationships. It results in a limited opportunity to articulate multidimensional experiences, as they are not recognised as parts of mainstream public debates on LGBT, or disability. Given this discursive separateness, when it comes to possible attachments and a sense of belonging to queer or disabled communities, non-heteronormative women may feel 'out of place'-that 
is, excluded from both, or not able to fully participate in any, due to their complex, intersectional positions. This deprives them of (or hinders access to) an important, community-based source of support.

As a result of the separateness/gap between the discourse of care as the primary attribute of disability (D'Auost, 1996; Shakespeare, 1996, 2014; Wade, 1994) and what may be characterised as moral panic around non-heteronormativity (Zielińska, 2015), homosexual relationships are often read as non-romantic, non-sexual, and being based on care. This situation diminishes the ontology of queer relationships and deprives women of subjective identification. By taking away the opportunity to define a relationship as intimate or to come out as a queer person, relationships between women are pushed to be read exclusively in terms of a charity model, where the disabled person is only a recipient. The social perception of women's relationships when one has a disability—mediated by the category of care—confirms the thesis about the totalising nature of disability as an identity feature, i.e., the belief that a person with disabilities is in a weaker position and should, therefore, be looked after.

The public policy framework of care tends to delegate care responsibilities to family, especially to women. In the absence of systemic solutions aimed at supporting disabled individuals with independent living, the relation to the family of origin becomes the major source of broadly understood care. Considering the polarisation of attitudes towards LGBT persons in Poland, it results in queer disabled women being obliged to carefully navigate between their non-heterosexual identities and required family support. The choice of disclosing one's sexual orientation is conditioned by dependence on family and dispersed and non-responsive support institutions, and also the risk of being excluded from care due to homophobia (Samuels, 2003). Addressing disability support to families instead of individuals results in constant navigation of homosexuality to receive needed care while avoiding ostracism. Separation from the family, for persons who require intensive care, means choosing between moving to an institution or buying care services from the private sector. In legal terms, living as a same-sex couple means being perceived as single, or in an unprotected (thus often economically and socially precarious) same-sex coupledom.

In care settings outside of a family home, disability generates more frequent or intensified relations with care institutions including health care, rehabilitation, or boarding schools. The experiences of queer disabled women reveal the assumption of omnipresent heterosexuality in those interactions, low responsiveness of the system to their needs, and incidents of denial of care when they disclose sexual orientation. The homophobic claims in political discourse may result in perceptions of institutionalised care as even more threatening: potential control over disabled bodies and their desires. Intensified homophobic claims in public institutions at the highest levels of governance legitimise the explicit articulation of homophobia and enhance discrimination within the organisational culture.

The analysis shows that the complex interplay between gender, disability, and non-heterosexuality places women among competing (and sometimes internally contradictory) discourses, through which they undertake complex navigations. Being situated 'in-between', non-heterosexual women with disabilities experience (and resist) institutionalised ableist and heteronormative regimes that do not account for their intersectional needs. The access to essential care for non-heterosexual disabled women is limited: the institutions remain hostile, the families of origin have explicit power to accept or reject them, and same-sex coupledom is not recognised or protected legally. All these factors may lead to further alienation of disabled women from their communities as they contribute to tension between obtaining everyday care and support, and disclosing one's identity and practices.

\section{Policy Implications}

Our findings have both theoretical and practical significance. At the theoretical level, the results of our research contribute to the corpus of literature on disability, care, and sexuality. The article explores the multiple, shifting ways in which disability intersects with other sources of social disadvantage. Intersectional understandings of disability reveal the multiple dynamics that may have an impact upon constructing support networks. Intersectional approaches destabilise reductionist accounts of medical approach and prioritise a social justice framework for tackling wider systemic rigidities and oppressive care regimes.

To date, very little academic research has focused on the population of LGBT people with disabilities; no reliable statistics exist to indicate the size of this population, as the research that focuses on people with disabilities rarely (if ever) inquires about sexual orientation (and vice versa) (Frayley et al., 2007). There are many potential directions for empirical research within this population, beyond identifying and counting them, e.g., the issue of personal assistance services. This can be explored in several ways, including determining the circumstances and frequency of disclosure of sexual orientation to personal assistants, or other support sources.

Such findings also have practical significance, as education about disability, and the impact that might have on social policy and care could ultimately improve the quality of society for all women, regardless of their disability status. The results of our research suggest that the intersection of disability and sexual orientation causes multilevel difficulties in women's access to care. The current 
care system is primarily normative and focuses on ideal or desired recipients, who require typical interventions and procedures. Disability is a complex and heterogeneous phenomenon that demands considerable interpretational effort (Livneh \& Parker, 2005; Room, 2011). If the support system is to fulfil its mission of providing adequate support for people with disabilities, then the different identity conditions of these people should be acknowledged (e.g., gender, age, sexual orientation, ethnicity) (Wołowicz et al., 2020). If the disability policy is to be intelligent, effective, responsive, and flexible, it has to be sensitive to the complexity and systemic nature of the problems being tackled. Access to support and care are part of human rights, though these will have no true meaning for people with disabilities unless they are implemented in practice-in a way that takes lived experiences of people with disabilities into account. Thus, it is clear that social support systems must better address citizens' intersectional needs.

Author Contribution All authors have an equal share in the work on the text and took part in all stages of the work.

Funding Preparation of this article was supported by grants from the National Science Centre, Poland UMO-2018/31/B/HS6/01041

\section{Declarations}

Informed Consent Before starting each interview, the researcher explained the purpose and content of the interview and answered any questions participants had. Informed consent was obtained from each of the participants (participants who could not sign a written consent form or did not feel comfortable signing a consent form were permitted to give verbal consent). For the consent to be informed, the person giving it must, first of all, understand what the study is about, and secondly, voluntarily agree to participate in it. The study was conducted only after ensuring that a potential participant had understood the information. There was no external pressure exerted to participate, and no one indicated any discomfort during or after the interview regarding our recruitment strategy. After the interview, the interviewees received a small gift to thank them for their time, which they were not informed of before the study, as the researchers thought that it could be seen as a form of pressure. Women with disabilities were informed about the possibility of refusing to participate in the study, without giving any reason, at every stage of its duration.

Conflict of Interest It was reported by the author(s). This material is the authors' own original work, which has not been previously published elsewhere.

Research Involving Human Participants and/or Animals The study was conducted in accordance with the principles of ethics in social research. The recommendations for research in the Convention on the Rights of Person with Disabilities (CRPD) were also considered (e.g., Article 31). The researchers were women-scientists with many years of experience in disability studies and/or queer studies. Accessibility was centred, so that methods used were comfortable to all participants. This enabled and allowed participation by women who were historically denied involvement in research and academic investigations.
Open Access This article is licensed under a Creative Commons Attribution 4.0 International License, which permits use, sharing, adaptation, distribution and reproduction in any medium or format, as long as you give appropriate credit to the original author(s) and the source, provide a link to the Creative Commons licence, and indicate if changes were made. The images or other third party material in this article are included in the article's Creative Commons licence, unless indicated otherwise in a credit line to the material. If material is not included in the article's Creative Commons licence and your intended use is not permitted by statutory regulation or exceeds the permitted use, you will need to obtain permission directly from the copyright holder. To view a copy of this licence, visit http://creativecommons.org/licenses/by/4.0/.

\section{References}

Bakalarczyk, R. (2015). System oparty na nie wspomaganej rodzinie. In Niepetnosprawnośc: problemy opieki. Warszawskie Debaty o Polityce Społecznej (pp. 10-18). Warszawa: Fundacja Międzynarodowe Centrum Badań i Analiz.

Ciaputa, E., Król, A., \& Warat, M. (2014). Macierzyństwo kobiet z niepełnosprawnościami ruchu, wzroku i słuchu. Studia Socjologiczne, 2(13), 203-224.

Crenshaw, K. (2009). Demarginalizing the intersection. In E. Grabham, D. Cooper, J. Krishnadas \& D. Herman (Eds.), Intersectionality and beyond. Law, power and the politics of location. New York: Routledge \& Cavendish.

D'Aoust, V. (1996). Which map is not whose territory? In S. Tremain (Ed.), Pushing the limits: Disabled dykes produce culture. (pp. 172-187). Women's Press.

Douglas, P., Rice, C., \& Kelly, C. (2017). Cripping care: Care pedagogies and practices. Review of Disability Studies: An International Journal, 13(4), 3-11.

Engster, D. (2005). Rethinking care theory: The practice of caring and the obligation to care. Hypatia, 20(3), 50-74. https://doi. org/10.1111/j.1527-2001.2005.tb00486.x

Evans, R., \& Atim, A. (2011). Care, Disability and HIV in Africa: Diverging or interconnected concepts and practices? Third World Quarterly, 32(8), 1437-1454. https://doi.org/10.1080/ 01436597.2011 .604517

Ferens, D., \& Sikora, T. (2016). Ugly bodies: Queer perspectives on illness, disability, and aging. Interalia, 11.

Fraley, S. S., Mona, L. R., \& Theodore, P. S. (2007). The sexual lives of lesbian, gay, and bisexual people with disabilities: Psychological perspectives. Sexuality Research \& Social Policy, 4, 15-26. https://doi.org/10.1525/srsp.2007.4.1.15

Gąciarz, B. (2014). Przemyśleć niepełnosprawność na nowo. Od instytucji państwa opiekuńczego do integracji i aktywizacji społecznej. Studia Socjologiczne, 2(213), 15-42.

Godzisz, P., \& Viggiani, G. (2019). Awareness of anti-LGBT hate crime in the European Union. Lambda.

Graham, H. (1983). Caring: A labour of love. In J. Finch \& D. Groves (Eds.), A labour of love: Women, work and caring. (pp. 13-30). Routledge and Kegan Paul.

GUS. (2016). Stan zdrowia ludności Polski w 2014 roku. Główny Urząd Statystyczny.

Hall, D. (2016). W poszukiwaniu miejsca. Chrześcijanie LGBT w Polsce. IFIS PAN.

Hill Collins, P., \& Bilge, S. (2016). Intersectionality. Polity Press.

Hochschild, A. R. (1995). The culture of politics: Traditional, postmodern, cold-modern, and warm-modern ideals of care. Social Politics, 2(3), 331-346. https://doi.org/10.1093/sp/2.3.331

Hryciuk, R., \& Korolczuk, E. (2013). At the intersection and class: social mobilization around mothers' rights in Poland. In K. 
Jacobsson \& S. Saxonberg (Eds.), Beyond NGO-ization? The Development of Social Movements in Central and Eastern Europe. (pp. 49-70). Ashgate.

Hwang, R. (2019). Deviant care for deviant futures: QTBIPoC Radical relationalism as mutual aid against carceral care. Transgender Studies Quarterly, 6(4), 559-578. https://doi. org/10.1215/23289252-7771723

Kittay, E. F. (1999). Love's labor. Essays on women, equality, and dependency. New York: Routledge.

Kittay, E. F. (2011). The ethics of care, dependence, and disability. Ratio Juris, 24(1), 49-58. https://doi.org/10.1111/j.1467-9337. 2010.00473.x

Korolczuk, E. (2020). The fight against 'gender' and 'LGBT ideology': New developments in Poland. European Journal of Politics and Gender, 3(1), 165-167. https://doi.org/10.1332/ 251510819X15744244471843

Korolczuk, E. (2019). The fight against 'gender' and 'LGBT ideology': New developments in Poland. European Journal of Politics and Gender 3(1), 165-167.

Korolczuk, E., \& Graff, A. (2018). Gender as "Ebola from Brussels": The anticolonial frame and the rise of illiberal populism. Signs: Journal of Women in Culture and Society, 43(4), 797-821. https:// doi.org/10.1086/696691

Kováts, E. (2018). Questioning consensuses: Right-wing populism, anti-populism, and the threat of 'gender ideology.' Sociological Research Online, 23(2), 528-538. https://doi.org/10.1177/ 1360780418764735

KPH (2016). Situation of LGBTA Persons in Poland, online: https:// kph.org.pl/wp-content/uploads/2019/07/Situation-of-LGBTAPersons-in-Poland-10.07.pdf

Król, A., Pustułka, P. (2018). Women on strike: mobilizing against reproductive injustice in Poland. International Feminist Journal of Politics 20(3), 366-384.

Kröger, T. (2009). Care research and disability studies: Nothing in common? Critical Social Policy, 29(3), 398-420. https://doi.org/ 10.1177/0261018309105177

Król, A. (2018). Niepełnosprawność i sprawiedliwość reprodukcyjna. Zarys wybranych zagadnień dotyczących kobiet z niepełnosprawnościami. Annales Universitatis Paedagogicae Cracoviensis. Studia de Cultura 10(1), 84-99.

Kubicki, P. (2015). Rodzice dzieci z niepełnosprawnością. Analiza polityk publicznych we wspótczesnej Polsce. In R. Hryciuk \& E. Korolczuk (Eds.), Niebezpieczne zwiazki. Macierzyństwo, ojcostwo i polityka, (pp. 133-158). Warszawa: UW.

Kubicki, P. (2017). Polityka publiczna wobec osób z niepetnosprawnościami. SGH.

Kubisa, J., \& Rakowska, K. (2018). Was it a strike? Notes on the Polish women's strike and the strike of parents of persons with disabilities. Praktyka Teoretyczna, 30(4), 15-50. https://doi.org/ 10.14746/prt.2018.4.1

Livneh, H., \& Parker, R. M. (2005). Psychological adaptation to disability: Perspectives from chaos theory and complexity theory. Rehabilitation Counseling Bulletin, 49(1), 17-28.

Mizielińska, J., Abramowicz, M., \& Stasińska, A. (2014). Rodziny z wyboru $w$ Polsce. IP PAN.

Mizielińska, J., Struzik, J., \& Król, A. (2017). Różnym głosem. Rodziny $\mathrm{z}$ wyboru w Polsce. Warszawa: PWN.

Mladenov, T. (2017). Postsocialist disability matrix. Scandinavian Journal of Disability Research, 19(2), 104-117.

Prilleltensky, O. (2003). A ramp to motherhood: The experiences of mothers with physical disabilities. Sexuality \& Disability, 21, 21-47.

Pustułka, P. (2015). Ethnic, gender and class identities of Polish migrant mothers: intersecting maternal narratives with transnationalism and integration. Social Identities, 22(1), 44-61.
Rawłuszko, M. (2019). And if the opponents of gender ideology are right? Gender politics, Europeanization, and the democratic deficit. Politics \& Gender, 1-23.

Room, G. (2011). Complexity, institutions and public policy: Agile decision-making in a turbulent world. Edward Elgar.

Rubin, A., \& Babbie, E. (2010). Essential research methods for social works. Brooks/Cole.

Samuels, E. (2003). My body, my closet: invisible disability and the limits of coming-out discourse. GLQ: A Journal of Lesbian and Gay Studies, 9(1-2), 233-256.

Saxton, M., Curry, M.A., Powers, L. E., Maley, S., Eckels, K., \& Gross, J (2001). "Bring my scooter so I can leave": A study of disabled women handling abuse by personal assistance providers. Violence Against Women, 7(4), 393-417. https://doi.org/10.1177/ 10778010122182523

Schwarzenbach, S. (1996). On civic friendship. Ethics, 107, 97-128

Shakespeare, T. (1996). Disability, identity and differences. In C. Barnes, \& G. Mercer (Eds.), Exploring the Divide. Leeds: The Disability Press.

Shakespeare, T. (2014). Disability rights and wrongs revisited. Routledge.

Shore, C., \& Wright, S. (2011). Conceptualising policy: Technologies of governance and the politics of visibility. In C. Shore, S. Wright \& D. Però (Eds.), Policy worlds: Anthropology and the analysis of contemporary power (pp. 1-26). Berghahn Books.

Skrzypek, M. (2018). The social and clinical determinants of proportions between paternalism and partnership in therapeutic relationships in medicine. Polish Journal of Public Health, 127(4), 176-181.

Smith-Chandler, N., \& Swart, E. (2014). In their own voices: Methodological considerations in narrative disability research. Qualitative Health Research, 24(3), 420-430. https://doi.org/10.1177/ 1049732314523841

Struzik, J. (2012). Sytuacja społeczna lesbijek i kobiet biseksualnych w Polsce. Stan badań. In Niewidoczne (dla) społeczności(pp.35-48). Kraków: Fundacja Przestrzeń Kobiet.

Struzik, J. (2015). Spoza centrum widać więcej. Przeciwdziałanie dyskryminacji krzyżowej ze względu na płeć, orientację seksualną i miejsce zamieszkania. Kraków: Fundacja Przestrzeń Kobiet.

Struzik, J. (2020). Framing Queer Activism in Poland: From Liberal Values to Solidarity. In: R. Buyantueva \& M. Shevtsova (Eds.), LGBTQ+ Activism in Central and Eastern Europe (pp. 265-288). Springer International Publishing. https://doi.org/10.1007/978-3030-20401-3_11

Szelewa, D. (2017). From implicit to explicit familialism: Post-1989 family policy reforms in Poland. In D. Auth, J. Hergenhan, \& B. Holland-Cunz (Eds.), Gender and family in European economic policy: Developments in the new millennium. (pp. 129-151). Springer International Publishing.

Thomas, C. (1999). Female forms: experiencing and understanding disability. Open University Press.

Ticktin, M. (2011). Casualties of care: Immigration and the politics of humanitarianism in France. University of California Press.

Titkow, A., Duch-Krzystoszek, D., \& Budrowska, B. (2004). Nieodptatna praca kobiet. Mity, realia, perspektywy. Warszawa: Wydawnictwo IFIS PAN.

Traustadóttir, R, (2006). Disability and gender: Introduction to the special issue. Scandinavian Journal of Disability Research, 8(2-3), 81-84.

Wade, Ch. M. (1994). Identity. Disability rag and resource, 32-36.

Wołowicz, A., Kocejko, M., Ferenc, K. (2020). Women with disabilities and access to gynaecological services in Poland. Disability \& Society.https://doi.org/10.1080/09687599.2020.1833310

Wołowicz-Ruszkowska, A. (2016). How Polish Women With Disabilities Challenge the Meaning of Motherhood. Psychology of Women Quarterly 40(1), 80-95. 
Żeglicka, K., Szarota, M., Król, A. (2019). Feministycznie o niepełnosprawności. Manifesta/utopia. In: K. Slany, J. Struzik, M. Ślusarczyk, B. Kowalska, M. Warat, E. Krzaklewska, E. Ciaputa, A. Ratecka, A. Król. Utopie kobiet. 100 lat praw wyborczych kobiet (1918-2018) (pp. 69-76). Kraków: Wydawnictwo Uniwersytetu Jagiellońskiego.

Zielińska, K. (2015). The Roman Catholic church and human rights in Poland. In H. G. Ziebertz \& G. Črpić (Eds.), Religion and human rights. An international perspective (pp. 137 - 149). Cham: Springer.

Publisher's Note Springer Nature remains neutral with regard to jurisdictional claims in published maps and institutional affiliations. 